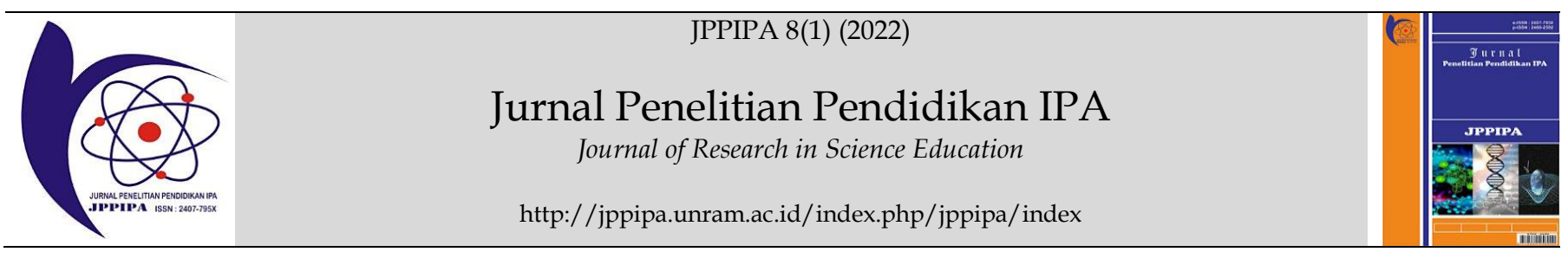

\title{
HOTSCC-Ichsan: HOTS of Climate Change with Ichsan's Taxonomy for Elementary Teacher Candidates
}

\author{
Ilmi Zajuli Ichsan ${ }^{*}$, Diana Vivanti Sigit² ${ }^{2}$ Nur Fadli Hazhar Fachrial ${ }^{3}$, Sri Nurafifah ${ }^{1}$, Ahmad Ali ${ }^{4}$, \\ Maricar H. Sison ${ }^{5}$, Nurfadhilah', Rika Sa' diyah, Yusi Rahmaniar8
}

\footnotetext{
${ }^{1}$ Elementary Teacher Education Program, Universitas Mohammad Husni Thamrin, Indonesia

${ }^{2}$ Biology Education Program, Universitas Negeri Jakarta, Indonesia

${ }^{3}$ Elementary Teacher Education Program, STKIP Arrahmaniyah, Indonesia

${ }^{4}$ Biology Education Program, UIN Alauddin Makassar, Indonesia

${ }^{5}$ College of Education, Nueva Ecija University of Science and Technology, Philippines

${ }^{6}$ Public Health Program, Universitas Muhammadiyah Jakarta, Indonesia

${ }^{7}$ Islamic Educational Management Program, Universitas Muhammadiyah Jakarta, Indonesia

${ }^{8}$ Higher Education Management, Business school, Institut Pertanian Bogor, Indonesia
}

DOI: $\underline{10.29303 / \text { ippipa.v8i1.930 }}$

\section{Article Info}

Received: September 4, 2021

Revised: December 24, 2021

Accepted: January 1, 2022

Published: January 31, 2022

\begin{abstract}
It is a necessity to develop environmental learning to solve climate change problems, in particular. One of the focuses is climate change learning at the elementary school level that requires elementary teacher candidates to understand various climate change issues. Skills needed are Higher Order Thinking Skills (HOTS) measurable using Ichsan's taxonomy as an innovation. Ichsan's taxonomy consists of six thinking levels, namely identify, compare, implement, criticize problems, solve problems, and develop innovation. The study describes the HOTS of elementary teacher candidates using the HOTS of Climate Change with Ichsan's taxonomy (HOTSCC-Ichsan). The study uses a descriptive method with a survey as the data collection technique. The study finds that the HOTS scores of the elementary teacher candidates measured using the HOTSCC-Ichsan are in a very low category (28.03). The finding indicates the need to enhance the HOTS-based learning intensively for the elementary teacher candidates. It requires learning media development to address the low HOTS. The research conclusion is that the HOTS of the elementary teacher candidates is low and needs an improvement.
\end{abstract}

Keywords: Climate change; Higher Order Thinking Skills; Ichsan's Taxonomy

Citation: Ichsan, I.Z., Sigit, D.V., Fachrial, N.F.H., Nurafifah, S., Ali, A., Sison, M.H., Nurfadhilah, N., Sa'diyah, R., \& Rahmaniar, Y. (2022). HOTSCC-Ichsan: HOTS of Climate Change with Ichsan's Taxonomy for Elementary Teacher Candidates. Jurnal Penelitian Pendidikan IPA, 8(1), 13-17. https:// doi.org/10.29303/jppipa.v8i1.930

\section{Introduction}

Climate change is a global issue that needs to be solved together. The impacts of the issue have gradually been felt. The impacts start from the change in sea level, reduced rainfall at certain times, and the shift in climate that occurs on a broader area scale. Different methods can be applied to anticipate the climate change impacts (Kauffman, et al., 2016; Mecklin, 2020; Strange, et al., 2011; Truelove \& Gillis, 2018). The methods include making policies in a certain area scale. The method, however, will not be effective if only several people implement it. All community components must implement the effort.

Students are one of the important components in a society that can manage climate change issues and their impacts. Students who study elementary school teacher education are an important component to educate students at the elementary school level. The students who are elementary teacher candidates will provide education related to the environment in the future. Therefore, they must possess climate change

\footnotetext{
*Email: $\underline{\text { ilmi.z.ichsan@gmail.com }}$
} 
knowledge. The required environmental knowledge

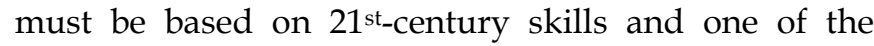
skills is the Higher Order Thinking Skills (HOTS) that is useful in solving problems (Aisyah, et al., 2018; Istiyono, et al., 2020; Tanujaya, 2016).

Previous studies in various students' HOTS measurements indicated a relatively low result (Ichsan, et al., 2019; Rochman \& Hartoyo, 2018; Saputri, et al., 2019). Diverse model development has been conducted to increase the HOTS (Husamah, et al., 2018; Muhlisin, et al., 2016). The efforts also include the development of various learning media to train the HOTS (Boholano, 2017; Reyna, et al., 2018). Further, the Higher Order Thinking Skills of Environmental Problem (HOTSEP) is developed to improve accuracy in the measurement of the environmental-related HOTS for environmental education at all levels (Ichsan \& Rahmayanti, 2020). Moreover, aiming to develop a taxonomy that can be used more relevantly, a revision has been conducted on Anderson's taxonomy by changing the thinking skill dimensions. The new taxonomy consists of thinking levels 1 to 6 , namely (1) identity (1) identify, (2) compare, (3) implement, (4) criticize problems, (5) solve problems, and (6) develop innovation (Ichsan et al., 2021). The change in the taxonomy is intended to have a more focused measurement of student skills. The HOTS realms in the Ichsan's taxonomy are at levels 4, 5 , and 6.

Based on the research results, the use of the HOTS in Ichsan's taxonomy needs to be implemented in learning, which is in the environmental learning related to climate change for the elementary teacher candidates. The HOTS in solving climate change is crucial due to the severity of the climate change problems. The elementary teacher candidates are expected to provide examples and education to students at the elementary school level on the importance of maintaining the environment from climate change. Hence, the study describes the HOTS of Climate Change with Ichsan's Taxonomy (HOTSCCIchsan).

\section{Method}

The research used a descriptive method with a survey as the data collection technique. The research was conducted in August 2021 and students in the Department of Elementary Teacher Education who are elementary teacher candidates were selected as the research sample. The sample consisted of 145 elementary teacher candidates selected using a simple random sampling technique. The instrument prepared was the Higher Order Thinking Skills of Climate Change based on Ichsan's Taxonomy (HOTSCC-
Ichsan). The thinking levels (TL) employed were started from levels 4, 5, and 6 (Ichsan et al., 2021). The description of the instrument specification is presented in Table 1.

Table 1. Specification of the HOTSCC-Ichsan Instrument

\begin{tabular}{lll}
\hline Thinking Level & Indicators & Item no \\
\hline $\begin{array}{l}\text { Criticize Problem } \\
\text { (TL-4) }\end{array}$ & $\begin{array}{l}\text { Criticize the climate } \\
\text { change-related } \\
\text { environmental pollutions } \\
\text { in urban areas }\end{array}$ & \\
Criticize Problem & $\begin{array}{l}\text { Criticize the handling of } \\
\text { environmental problems } \\
\text { in the surrounding areas }\end{array}$ & 3,4 \\
Solve Problem & $\begin{array}{l}\text { Provide solutions to } \\
\text { waste management to } \\
\text { prevent climate change }\end{array}$ & 5,6 \\
Solve Problem & $\begin{array}{l}\text { Provide solutions to the } \\
\text { lack of education related } \\
\text { (TL-5) }\end{array}$ & 7,8 \\
$\begin{array}{l}\text { to styrofoam use } \\
\text { Develop }\end{array}$ & $\begin{array}{l}\text { innovelop learning } \\
\text { intriguing programs for } \\
\text { climate change education }\end{array}$ & \\
& $\begin{array}{l}\text { Develop an innovation of } \\
\text { social media use and the } \\
\text { roles of communities in } \\
\text { the climate change } \\
\text { education }\end{array}$ & \\
$\begin{array}{l}\text { Develop } \\
\text { Innovation (TL-6) }\end{array}$ & 9,10 \\
\hline
\end{tabular}

Once data were collected using the HOTSCCIchsan instrument, the data were processed using Microsoft Excel and the Statistical Package for the Social Sciences (SPSS). The validity test employed the Pearson Correlation, whereas the reliability test used the Spearman-Brown. The results of the validity and reliability test of the instruments are indicated in Table 2.

Table 2. Results of the Validity test of the HOTSCCIchsan instrument

\begin{tabular}{lll}
\hline Item & Pearson Correlation & Category \\
\hline Item 1 & $.675^{* *}$ & Valid \\
Item 2 & $.758^{* *}$ & Valid \\
Item 3 & $.724^{* *}$ & Valid \\
Item 4 & $.603^{* *}$ & Valid \\
Item 5 & $.719^{* *}$ & Valid \\
Item 6 & $.583^{* *}$ & Valid \\
Item 7 & $.595^{* *}$ & Valid \\
Item 8 & $.695^{* *}$ & Valid \\
Item 9 & $.560^{* *}$ & Valid \\
Item 10 & $.627^{* *}$ & Valid \\
Item 11 & $.610^{* *}$ & Valid \\
Item 12 & $.547^{* *}$ & Valid \\
\hline
\end{tabular}

The reliability calculation derives a result of 0.81 ; thus, the HOTSCC-Ichsan can be used for the 
measurement. Data analysis was conducted after the instrument validity test by calculating the average HOTS score of the elementary teacher candidates. The score was then compared between the indicators and aspects according to the specification table.

\section{Result and Discussion}

The research results indicate that the HOTS scores of the elementary teacher candidates measured using the HOTSCC-Ichsan were still not optimal. Various items of the HOTS scores required an improvement, namely in the $10^{\text {th }}$ and $11^{\text {th }}$ items that related to the use of learning media and social media to prevent climate change. The two items were in the TL-6 suggesting that the students' scores were still low in developing learning innovations. Detail of the score is presented in Table 3.

Table 3. The HOTS scores measured using the HOTSCC-Ichsan for each item

\begin{tabular}{|c|c|}
\hline Item & Score \\
\hline $\begin{array}{l}\text { Criticize the climate change-related } \\
\text { environmental pollutions in urban areas }\end{array}$ & 4.06 \\
\hline $\begin{array}{l}\text { Criticize the issue of the use of plastic bags on } \\
\text { climate change }\end{array}$ & 3.28 \\
\hline $\begin{array}{l}\text { Criticize the disposal of mask waste that has } \\
\text { an impact on climate change }\end{array}$ & 2.97 \\
\hline $\begin{array}{l}\text { Give criticism and suggestions on the handling } \\
\text { of climate change prevention in the } \\
\text { surrounding environment }\end{array}$ & 2.98 \\
\hline $\begin{array}{l}\text { Provide solutions to waste burning problem } \\
\text { that has impacts on climate change }\end{array}$ & 2.78 \\
\hline $\begin{array}{l}\text { Provide solutions to a saving mask usage to } \\
\text { prevent the accumulation of garbage }\end{array}$ & 2.70 \\
\hline $\begin{array}{l}\text { Provide solutions to Styrofoam use problem to } \\
\text { the elementary school students }\end{array}$ & 2.63 \\
\hline $\begin{array}{l}\text { Provide solutions to the lack of education to } \\
\text { the elementary school students on climate } \\
\text { change }\end{array}$ & 2.64 \\
\hline $\begin{array}{l}\text { Develop an innovation of out-of-school } \\
\text { programs for the elementary school students } \\
\text { to understand climate change }\end{array}$ & 2.51 \\
\hline $\begin{array}{l}\text { Develop ideas on the use of interesting } \\
\text { learning media for the elementary school } \\
\text { students }\end{array}$ & 2.26 \\
\hline $\begin{array}{l}\text { Develop innovations related to the use of } \\
\text { social media for climate change education }\end{array}$ & 2.31 \\
\hline $\begin{array}{l}\text { Develop innovations related to the roles of } \\
\text { parents and communities in climate change- } \\
\text { related education for the elementary school } \\
\text { students }\end{array}$ & 2.52 \\
\hline Average Score (scale 0-100) & 28.03 \\
\hline Category & Very low \\
\hline
\end{tabular}

Table 4 indicates the HOTS scores measured using the HOTSCC-Ichsan for each indicator. The measurement results suggest that the lowest scores were in the indicators for developing innovations of social media use and the role of communities in climate change education.

Table 4. The HOTS score measured using the HOTSCC-Ichsan for each indicator

\begin{tabular}{lll}
\hline Indicators & Score \\
\hline $\begin{array}{l}\text { Criticize the climate change-related } \\
\text { environmental pollutions in urban areas }\end{array}$ & 3.67 \\
$\begin{array}{l}\text { Criticize the handling of environmental } \\
\text { problems in the surrounding area }\end{array}$ & 2.98 \\
$\begin{array}{l}\text { Provide solutions to waste management to } \\
\text { prevent climate change problem }\end{array}$ & 2.74 \\
$\begin{array}{l}\text { Provide solutions to the lack of education } \\
\text { related to styrofoam use }\end{array}$ & 2.63 \\
$\begin{array}{l}\text { Develop learning innovations and intriguing } \\
\text { programs for climate change education }\end{array}$ & 2.38 \\
$\begin{array}{l}\text { Develop an innovation of social media use and } \\
\text { the role of communities in the climate change } \\
\text { education }\end{array}$ & 2.41 \\
\hline
\end{tabular}

The measurement results based on the TL indicate that the lowest score was in the TL-6. The results were consistent with the results in the measurement based on the indicator and for each item. It suggests that the lowest TL score requires further improvement in terms of thinking patterns that lead to the development of innovation.

Table 5. The HOTS score measured using the HOTSCC-Ichsan for each Thinking Level

\begin{tabular}{ll}
\hline Thinking Level & Score \\
\hline Criticize Problem (TL-4) & 3.32 \\
Solve Problem (TL-5) & 2.69 \\
Develop Innovation (TL-6) & 2.40 \\
\hline
\end{tabular}

The research results imply that the HOTS of the elementary teacher candidates need an improvement using various models, media, and learning strategies. The efforts must be done in a structured and wellplanned manner.

Several studies supported the above findings that elementary school preservice teachers' HOTS competence can improve with material reinforcement and learning models that can support their HOTS (Atmojo, et al., 2017). In the study conducted by Malik, et al. (2018) revealed that the utilization of a Higherorder Thinking laboratory (HOT-Lab) in enhancing the critical skills of preservice teachers had a greater impact on improving their critical thinking skills on RCL circuit topic.

Students in the Department of Elementary Teacher Education will be a teacher someday. They must possess higher levels of education which leads them to greater expressed concern for the environment and the ability to comprehend complex environmental 
problems. They must be capable of High-level thinking rather than low-level thinking based on everyday knowledge, which is required to generate creative ideas. They must be equipped with information related to the environment, especially current issues on climate change. The issues become a problem focus that needs to be solved due to their global impacts. Environmental learning by examining various main topics will be relevant and contextual; hence, education is more directed at solving current problems (Abdul-Wahab \& Abdo, 2010; Cronje, et al., 2011; Garcia, 2015).

Climate change as an environmental issue requires studies and problem solving. The HOTS measured using the HOTSCC-Ichsan is expected to be an evaluation for universities to develop HOTS-based learning. Climate change learning can be implemented in the form of a specific course in the Department of Elementary Teacher Education. Additionally, development efforts can be conducted in the natural science course as additional content and topic. Environmental education is a field of science across the knowledge clusters (Hwang, et al., 2017; Surpless, et al., 2014).

The focus, however, is related to the learning development efforts that should put the HOTS learning steps forward. Different learning models can be selected to support the HOTS-based learning development. The selected learning model should aim to solve problems and provide innovation for the problem solutions. The learning model should be continuously implemented and modified with learning media; hence, the established learning can present critical and creative thinking models. The elementary teacher candidates need to be more innovative in developing various educational innovations that encourage the occurrence of innovation every year (Lee, 2016; Saleh \& Filawati, 2019; Seechaliao, 2017).

\section{Conclusion}

Based on the research results, it can be concluded that the HOTS score of the elementary teacher candidates measured using the HOTSCC-Ichsan was still in a very low category, especially in the $6^{\text {th }}$ thinking level. The results indicate the need to develop various and strategic HOTS-based learning models and media to improve the HOTS. The research suggests the development of teaching materials and learning media for climate change learning for elementary teacher candidates in the future due to the importance of environmental learning to solve climate change problems that need to be implemented at the elementary school level.

\section{References}

Abdul-Wahab, S. A., \& Abdo, J. (2010). The effects of demographic factors on the environmental awareness of Omani citizens. Human and Ecological Risk Assessment: An International Journal, 16(2), 380-401. https://doi.org/10.1080/10807031003670410

Aisyah, A., Salehuddin, K., Aman, I., Yasin, R. ., \& Mimiko, N. (2018). Eliciting elements of higher order thinking skills in the higher secondary examination question structure in japan and malaysia aznur. Proceedings of the Regional Conference on Science, Technology and Social Sciences (RCSTSS 2016), Rcstss 2016, 455-464. https://doi.org/10.1007/978-981-13-0074-5

Atmojo, I. R. W., Sajidan, S., Sunarno, W., \& Ashadi, A. (2017). Profile of elementary school pre-service teacher based on high order thinking skills (HOTS) on natural science subject. Proceedings of the International Conference on Teacher Training and Education 2017, 360-363. https:// doi.org/10.2991/ictte-17.2017.57

Boholano, H. B. (2017). Smart social networking: 21st century teaching and learning skills. Research in Pedagogy, 7(1), 21-29. https://doi.org/10.17810/2015.45

Cronje, R., Rohlinger, S., Crall, A., \& Newman, G. (2011). Does participation in citizen science improve scientific literacy? A study to compare assessment methods. Applied Environmental Education and Communication, 10(3), 135-145. https://doi.org/10.1080/1533015X.2011.603611

Garcia, L. C. (2015). Environmental science issues for higher-order thinking skills (hots) development: A case study in the Philippines. In Biology Education and Research in a Changing Planet (pp. 45-54). $\quad$ https://doi.org/10.1007/978-981-287$\underline{524-2}$

Husamah, H., Fatmawati, D., \& Setyawan, D. (2018). OIDDE learning model: Improving higher order thinking skills of biology teacher candidates. International Journal of Instruction, 11(2), 249-264. https://doi.org/10.12973/iji.2018.11217a

Hwang, Y. M., Kim, K. S., \& Im, T. (2017). Film scenes in interdisciplinary education: teaching the Internet of Things. Educational Media International, $\quad 54(2), \quad 83-98$. https://doi.org/10.1080/09523987.2017.1362832

Ichsan, I. Z., \& Rahmayanti, H. (2020). HOTSEP: Revised Anderson's taxonomy in environmental learning of COVID-19. European Journal of Educational Research, 9(3), 1257-1265. https://doi.org/10.12973/eu-jer.9.3.1257

Ichsan, I. Z., Rahmayanti, H., Purwanto, A., Sigit, D. V., 
Kurniawan, E., Tanjung, A., Panjaitan, R. G. P., Pertiwi, N., \& Singh, C. K. S. (2021). Thinking Level in Education: A Complete Revision of Anderson's Taxonomy. Pedagogika, 141(1), 53-78. https://doi.org/10.15823/p.2021.141.3

Ichsan, I. Z., Sigit, D. V., Miarsyah, M., Ali, A., Arif, W. P., \& Prayitno, T. A. (2019). HOTS-AEP: Higher order thinking skills from elementary to master students in environmental learning. European Journal of Educational Research, 8(4), 935-942. https://doi.org/10.12973/eu-jer.8.4.935

Istiyono, E., Dwandaru, W. S. B., Setiawan, R., \& Megawati, I. (2020). Developing of computerized adaptive testing to measure physics higher order thinking skills of senior high school students and its feasibility of use. European Journal of Educational Research, 9(1), 91-101. https://doi.org/10.12973/eu-jer.9.1.91

Kauffman, J. B., Trejo, H. H., Garcia, M. del C. J., Heider, C., \& Contreras, W. M. (2016). Carbon stocks of mangroves and losses arising from their conversion to cattle pastures in the Pantanos de Centla, Mexico. Wetlands Ecology and Management, 24(2), 203-216. https:// doi.org/10.1007/s11273-015-9453-Z

Lee, A. Y. L. (2016). Media education in the school 2.0 era: Teaching media literacy through laptop computers and iPads. Global Media and China, 1(4), 435-449. https:// doi.org/10.1177/2059436416667129

Malik, A., Setiawan, A., Suhandi, A., Permanasari, A., Samsudin, A., Safitri, D., Lisdiani, S. A. S., Sapriadil, S., \& Hermita, N. (2018). Using hot lab to increase pre-service physics teacher's critical thinking skills related to the topic of RLC circuit. Journal of Physics: Conference Series, 1013(1), 12023. https://doi.org/10.1088/17426596/1013/1/012023

Mecklin, J. (2020). The climate change evidence right before our eyes. And a note on COVID-19. Bulletin of the Atomic Scientists, 76(3), 119-120. https://doi.org/10.1080/00963402.2020.1753318

Muhlisin, A., Susilo, H., Amin, M., \& Rohman, F. (2016). Improving critical thinking skills of college students through RMS model for learning basic concepts in science. Asia-Pacific Forum on Science Learning and Teaching, 17(1), 1-24. Retrieved from: https://www.eduhk.hk/apfslt/v17_issue1/muh lisin/index.htm

Reyna, J., Hanham, J., \& Meier, P. (2018). The Internet explosion, digital media principles and implications to communicate effectively in the digital space. E-Learning and Digital Media, 15(1), 36-52. https://doi.org/10.1177/2042753018754361

Rochman, S., \& Hartoyo, Z. (2018). Analisis High Order Thinking Skills (HOTS) Taksonomi Menganalisis Permasalahan Fisika. Science and Physics Education Journal (SPEJ), 1(2), 78-88. https://doi.org/10.31539/spej.v1i2.268

Saleh, R., \& Filawati, F. (2019). Efektifitas penerapan model pembelajaran kooperatif tipe students team achievement division dalam meningkatkan aktivitas dan hasil belajar kognitif siswa. Edubiotik: Jurnal Pendidikan, Biologi Dan Terapan, 4(02), $75-82$. https://doi.org/10.33503/ebio.v4i02.449

Saputri, A. C., Sajidan, S., Rinanto, Y., Afandi, A., \& Prasetyanti, N. M. (2019). Improving students' critical thinking skills in cell-metabolism learning using stimulating higher order thinking skills model. International Journal of Instruction, 12(1), 327-342.

https://doi.org/10.29333/iji.2019.12122a

Seechaliao, T. (2017). Instructional strategies to support creativity and innovation in education. Journal of Education and Learning, 6(4), 201-208. https://doi.org/10.5539/jel.v6n4p201

Strange, N., Jellesmark, B., Bladt, J., Wilson, K. A., \& Rahbek, C. (2011). Conservation policies and planning under climate change. Biological Conservation, 144(12), 2968-2977. https://doi.org/10.1016/j.biocon.2011.08.022

Surpless, B., Bushey, M., \& Halx, M. (2014). Developing scientific literacy in introductory laboratory courses: A model for course design and assessment. Journal of Geoscience Education, 62(2), 244-263. https:// doi.org/10.5408/13-073.1

Tanujaya, B. (2016). Development of an instrument to measure higher order thinking skills in senior high school mathematics instruction. Journal of Education and Practice, 7(21), 144-148. Retrieved from:

https://www.iiste.org/Journals/index.php/JEP Larticle/view/31982

Truelove, H. B., \& Gillis, A. J. (2018). Perception of proenvironmental behavior. Global Environmental Change, 49(February), 175-185. https://doi.org/10.1016/j.gloenvcha.2018.02.009 